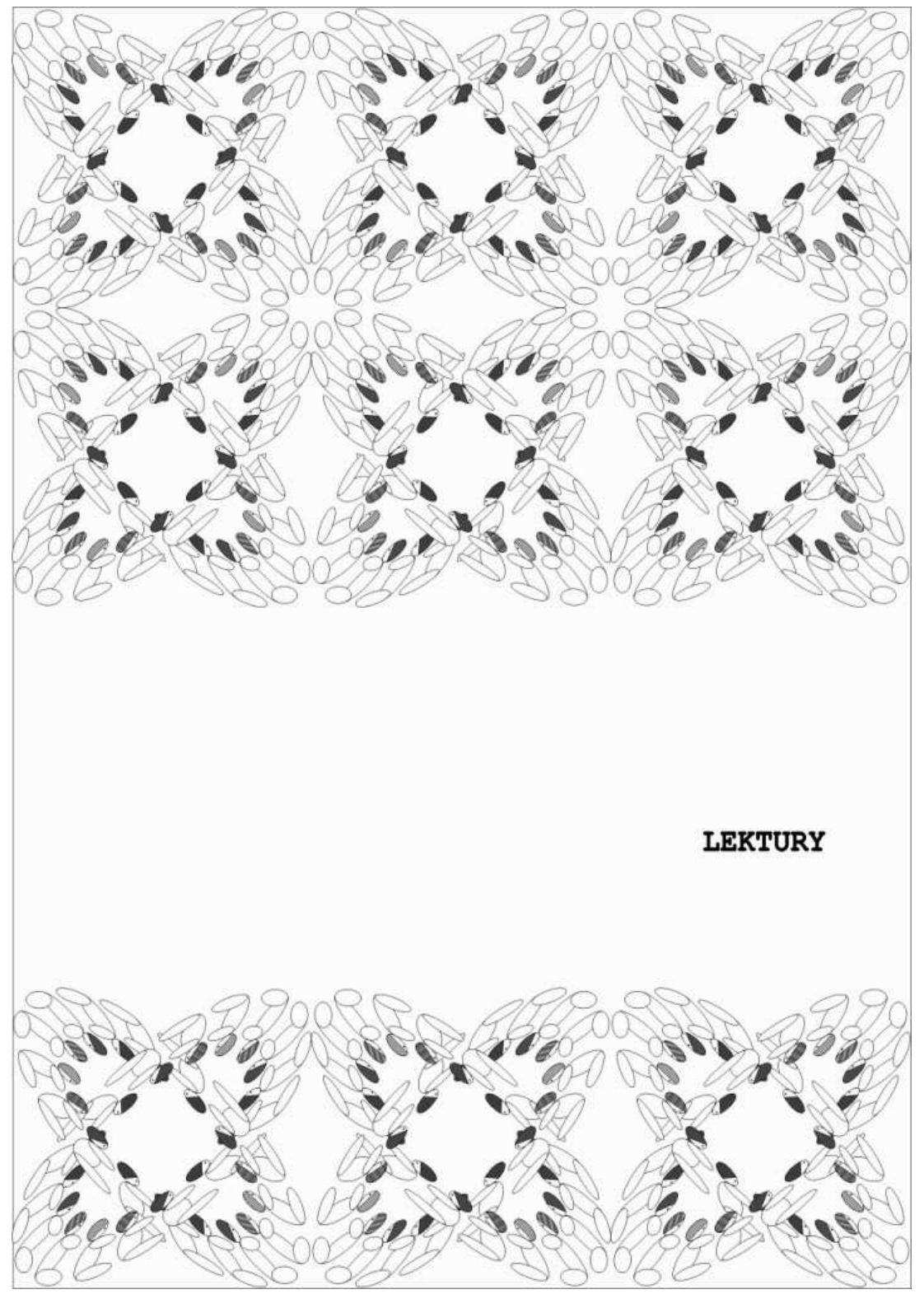





\section{„Književna istorija”, nr 145, Institut za književnost i umetnost, Beograd 2011, ss. 962}

\footnotetext{
Wydawany od 1968 roku przez Instytut Literatury i Sztuki (Institut za književnost i umetnost) w Belgradzie periodyk „Književna istorija” ukazuje się trzy razy w roku, obejmując niezwykle szerokie spektrum zagadnień związanych z komparatystyka, poetyką, estetyką, historią i teorią kultury oraz literatury. Umieszczane w czasopiśmie publikacje utrzymane są na wysokim poziomie merytorycznym. Umożliwiają specjalistom prezentację swych teorii, wyników badań oraz rozwiązań terminologicznych i metodologicznych z dziedziny nauki o literaturze. Materiał składa się z pięciu niezależnych części, podzielonych według kryterium tematycznego i merytoryczno-terminologicznego, począwszy od tekstów naukowych, na recenzjach skończywszy.

Prezentowany numer otwiera studium Bojana Đorđevicia, który analizuje dwa, dotąd niepublikowane, utwory dubrownickich literatów: wiersz Frana Getaldicia i poemat satyryczny Antuna Gleđevicia. Ich polemiczny wydźwięk naświetla charakter XVIII-wiecznego sporu pomiędzy dwiema instytucjami kulturalnymi, wokół których skupiali się dubrowniccy pisarze (Accademia degli Otiosi i Accademia degli Invidiati). Tekst Đorđevicia jawi się jako opracowanie szczególnie potrzebne, ukazuje bowiem mało zbadaną atmosferę kulturalną XVIII-wiecznego Dubrownika. Ljiljana Stošić z kolei omawia rolę moralizatorskich pouczeń biblijnych w twórczości Dositeja Obradovicia. Badaczka zwraca uwagę na fakt, że serbski działacz oświeceniowy opatrywał swe baśnie krótkimi komentarzami na temat ludzkich zalet i namiętności, które opisywał w odwołaniu do anegdotycznych przykładów, wzbogacanych cytatami bądź parafrazami psalmów, listów św. Pawła, ewangelicznych paraboli, Księgi Koheleta oraz Księgi Przypowieści Salomona. Przedstawiając wpływ Pisma Świętego na twórczość Obradovicia, badaczka umieszcza ją w szerszym kontekście kultu-
} 
rowym. Uwypukla ponadto jej specyfikę i oryginalność na tle europejskiej myśli oświeceniowej. Jelena Jovanović przypomina funkcjonujący na marginesach historii literatury wiersz Jovana Steriji Popovicia - Pohvala sliku (Pochwała rymowi), na którego niekorzystną recepcję wpłynął przede wszystkim dominujący paradygmat romantyczny. Z utworu Steriji Popovicia wydobyte zostały płaszczyzny intertekstualnych odniesień i wyeksponowano jego metatekstualny charakter nastawiony na oryginalną polemikę z poetycką szkołą Lukijana Mušickiego. Związki twórczości Lazy Kostcia i XVII-wiecznej poezji angielskiej bada Marta Frajnd, która wykracza poza standardowy poziom werbalno-stylistyczny, eksponując analogie duchowo-emocjonalne. Artykuł odznacza się dużą wartością poznawczą, znacznie bowiem poszerza tradycyjny kontekst interpretacyjny twórczości serbskiego pisarza.

Relacje między literaturą serbską a innymi literaturami europejskimi uczyniła przedmiotem swej analizy również Jasna Stojanović, zwracając uwagę na reminiscencję Don Kichota Cervantesa w utworze serbskiego pisarza z początku XX wieku - Don Kihot $u$ Vrapčanima Selimira Trpkovicia. W centrum zainteresowania autorki sytuuje się zwłaszcza bohater, skonstruowany zgodnie z romantyczną recepcją wiekopomnego dzieła Cervantesa. Boris Milosavljević poglądowo analizuje rolę Slobodana Jovanovicia w założeniu i we współpracy z serbskimi czasopismami: „Red”, „Srpski pregled”, „Srpski književni glasnik”. Działalność Jovanovicia rozpatrywana jest na tle politycznym. W tekście starannie zarysowano również panoramę ogólnych przekonań polityczno-filozoficznych i estetycznych serbskiego działacza. Na podobnym materiale tekstologicznym oparł swoje studium również Veljko Stanić, koncentrujący się na obecności tematyki francuskiej w czasopiśmie „Srpski književni glasnik”. W artykule dokonano kompetentnej analizy funkcjonowania specyficznego francuskiego modelu polityczno-kulturowego, implikującego przede wszystkim wizję Francji jako ideału wolności, w serbskich kręgach intelektualnych skupionych wokół periodyku „Srpski književni glasnik”. Dzięki temu badacz rekonstruuje sposób życia międzywojennej inteligencji serbskiej i diagnozuje jej polityczno-kulturowe przekonania oraz propagowane wartości. Nośny pod względem merytorycznym tekst Mileny Vladić Jovanov poświęcony jest poszukiwaniu tematów i idei powiązanych z koncepcją dekonstrukcji w twórczości Thomasa S. Eliota. Poprzez swoistą transfor- 
mację dziedzin wiedzy, tożsamości i samoświadomości w swym skomplikowanym systemie poetyckim, Eliot, według autorki, położył fundamenty przyszłych teorii dekonstrukcjonizmu Derridy. Do zachodnioeuropejskiej tradycji literackiej nawiązuje również Wolf Schmidt. Mimo że powieść Thomasa Manna Doktor Faustus była w przeszłości wielokrotnie studiowana $\mathrm{i}$ analizowana, badacz wydobywa $\mathrm{z}$ niej nowe sensy, oscylujące wokół centralnego tematu podpisania paktu z diabłem przez głównego bohatera - niemieckiego kompozytora Adriana Leverkühna. Z podwójnej narracji wyłania się kluczowa metafora powieści konotująca faszystowską przeszłość Niemiec, którą Mann usiłował przedstawić w swym „zakamuflowanym" utworze.

Serbska epika ludowa stanowi z kolei materiał badawczy w interesującym studium Aleksandra Pavlovicia, który przez pryzmat koncepcji politologicznych Carla Schmitta analizuje kreowanie obrazu politycznego przeciwnika. Podkreśla się przede wszystkim oddziaływanie władz Cetynia - istotnego centrum politycznego - na tradycję oralną, kreującą figurę politycznego wroga w XIX w. Pod wpływem polityki panującego rodu Petroviciów w literaturze ustnej uwypuklona została wrogość i wzajemny antagonizm pomiędzy Czarnogórcami a społecznością lokalnych Turków. Marija Grujić, autorka kolejnego studium, wnikliwie rozpatruje możliwości analizy różnorodnych konstrukcji kultury popularnej za pomocą aparatury pojęciowej teorii literatury. Odwołując się do koncepcji Stuarta Halla i Rolanda Barthes'a, badaczka traktuje różne rodzaje kultury popularnej jako systemy znakowe, które mogą być porównywane z innymi systemami powstałymi $\mathrm{w}$ określonym procesie historyczno-kulturowym. $\mathrm{W}$ tej perspektywie rzetelnej analizie zostały poddane teksty piosenek muzyki popularnej z epoki jugosłowiańskiej. Zorica Đergović-Joksimović i Ivana Đurić-Paunović podejmują podobny temat funkcjonalności kultury masowej. W świetle koncepcji Fredrica Jamesona o postmodernistycznym ,uprzestrzennieniu" kultury pod wpływem późnego kapitalizmu i teorii Lindy Hutcheon o historiograficznej metafikcji podjęto refleksję nad komiksem brytyjskiego pisarza Alana Moore'a Liga Niezwyktych Dżentelmenów i jego serbskim odpowiednikiem Družina Dardaneli (Drużyna Dardaneli) Pavla Zelicia. Autorzy rekanonizują i remitologizują XIX-wieczną literaturę (zarówno angielską, jak i serbska). Na płaszczyźnie metodologicznej, stosując w oryginalny i nowatorski sposób teorie Lubomira Doležela 
o światach możliwych i poststrukturalistyczną analizę semiotyczną, badaczki pokazują więzi pomiędzy różnymi fenomenami kulturowymi, takimi jak literatura i komiks.

$\mathrm{W}$ drugiej integralnej części czasopisma, dotyczącej terminologii z zakresu teorii literatury i kulturoznawstwa, znajduje się artykuł Bogusława Zielińskiego poświęcony analizie tak istotnego dla polskiego dyskursu tożsamościowego pojęcia Europy Środkowej. Za pomocą znakomicie dobranych tekstów skonstruowano klarowne i nowatorskie perspektywy oglądu koncepcji Europy Środkowej, będącej ponadnarodowym projektem kulturowym. W tekście przekonująco zostały ukazane trzy kluczowe modele funkcjonowania idei Europy Środkowej, jawiącej się jako Arkadia, Atlantyda i Jeruzalem. Przez ukazane modele dochodzi do twórczego przesunięcia semantycznego terminu (zawężonego przez triadę klasyków intelektualistów: Miłosza, Szűcsa i Kunderę), który zaczyna dzięki nim funkcjonować również w niezwykle zróżnicowanej bałkańskiej przestrzeni kulturowej.

Studium Biljany Andonovskiej stanowi kolejną część recenzowanego numeru. Jest ono rzetelnym przeglądem serbskich czasopism reprezentujących nurt awangardowy. Periodyk literacki traktowany jest tu jako uprzywilejowana forma komunikacji i specyficzne medium, funkcjonujące jako głos nowych grup poetyckich i ich programów. Na podstawie analizy tradycji serbskich almanachów i dokonanej typologii czasopism z lat dwudziestych XX wieku, badaczka przekonująco konstruuje specyficzny „,paradygmat almanachowy”, jawiący się jako zakodowana prawidłowość w korpusie modernistyczno-awangardowych czasopism.

W następnej części numeru Vidosava Golubović pierwszy raz publikuje list Marka Risticia do przyjaciółki Iriny Aleksander, mający formę epistolarnego eksperymentu. Nadawca bowiem wybrał formę swoistego kolażu, skonstruowanego na zasadzie dziecięcej zabawy, konotującej obyczaj ubierania bożonarodzeniowej choinki. Golubović opatrzyła list interesującym komentarzem, zwracając uwagę na emocje i duchowy stan nadawcy oraz adresata, które stają się szczególnie znaczące, zważywszy na czas powstania listu. Został on napisany w okresie bezpośrednio poprzedzającym agresję hitlerowską na Królestwo Jugosławii, dlatego atmosferę duchową pisma, zarówno werbalnie, jak i wizualnie, wypełnia przeczucie nadchodzącej katastrofy. 
Z kolei w studium Sylwii Nowak-Bajcar rekonstrukcja wydarzeń związanych z pobytem Iva Andricia w Krakowie opiera się na zachowanych dokumentach archiwalnych i zapisanych relacjach świadków. Wnikliwie zbadano wpływ krakowskiego okresu na kształtowanie literackiej tożsamości Andricia, wydobywając z niej subtelne niuanse i nowe fakty.

Periodyk kończy rozdział poświęcony polecanym lekturom, w którym znajdziemy czternaście recenzji dotyczących publikacji serbskich i zagranicznych z lat 2009-2011.

Prezentowany numer, ukazujący szeroki zakres zagadnień literaturoznawczych i kulturoznawczych, jest godny polecenia z uwagi na erudycyjny charakter, rzetelność i wnikliwość przedstawianych badań. Charakteryzuje się dużą wartością poznawcza, przez co może otwierać drogę do dalszych refleksji i rozważań. Umieszczone w tomie teksty są niezwykle zróżnicowane pod względem metodologicznym, merytorycznym, ideowym i informacyjnym - wszystkie są wartościowe, co niewątpliwie świadczy o wysokim poziomie naukowym Instytutu Literatury i Sztuki w Belgradzie.

Pawet Dziadul 